Article

\title{
Overcoming Hypoxia-Induced Chemoresistance in Cancer Using a Novel Glycoconjugate of Methotrexate
}

\author{
Marta Woźniak ${ }^{1}$, Gabriela Pastuch-Gawołek ${ }^{2,3}{ }^{\circledR}$, Sebastian Makuch ${ }^{1}$, Jerzy Wiśniewski ${ }^{4} \mathbb{D}$, Piotr Ziółkowski $^{1}$, \\ Wiesław Szeja ${ }^{2}$, Monika Krawczyk $2,3, *$ (D) and Siddarth Agrawal 1,5,*(D)
}

1 Department of Pathology, Wrocław Medical University, Marcinkowskiego 1, 50-368 Wrocław, Poland; marta.wozniak@umed.wroc.pl (M.W.); sebastian.mk21@gmail.com (S.M.); piotr.ziolkowski@umed.wroc.pl (P.Z.)

2 Department of Organic Chemistry, Bioorganic Chemistry and Biotechnology, Faculty of Chemistry, Silesian University of Technology, Krzywoustego 4, 44-100 Gliwice, Poland; gabriela.pastuch@polsl.pl (G.P.-G.); wieslaw.szeja@adres.pl (W.S.)

3 Biotechnology Centre, Silesian University of Technology, Krzywoustego 4, 44-100 Gliwice, Poland

4 Department of Medical Biochemistry, Wroclaw Medical University, Marcinkowskiego 1, 50-368 Wrocław, Poland; jerzy.wisniewski@umed.wroc.pl

5 Department and Clinic of Internal Medicine, Occupational Diseases, Hypertension and Clinical Oncology, Wroclaw Medical University, Marcinkowskiego 1, 50-368 Wrocław, Poland

* Correspondence: monika.krawczyk@polsl.pl (M.K.); siddarth@agrawal.pl (S.A.)

check for

updates

Citation: Woźniak, M.;

Pastuch-Gawołek, G.; Makuch, S.;

Wiśniewski, J.; Ziółkowski, P.; Szeja,

W.; Krawczyk, M.; Agrawal, S.

Overcoming Hypoxia-Induced

Chemoresistance in Cancer Using a

Novel Glycoconjugate of

Methotrexate. Pharmaceuticals 2021,

14, 13. https://dx.doi.org/10.3390

/ph14010013

Received: 24 November 2020

Accepted: 23 December 2020

Published: 24 December 2020

Publisher's Note: MDPI stays neutral with regard to jurisdictional claims in published maps and institutional affiliations.

Copyright: () 2020 by the authors. Licensee MDPI, Basel, Switzerland. This article is an open access article distributed under the terms and conditions of the Creative Commons Attribution (CC BY) license (https: / / creativecommons.org/ licenses/by/4.0/).

\begin{abstract}
The oxygen and nutrient-deprived tumor microenvironment is considered a key mechanism responsible for cancer resistance to chemotherapy. Methotrexate (MTX) is a widely incorporated chemotherapeutic agent employed in the treatment of several malignancies. However, drug resistance and systemic toxicity limit the curative effect in most cases. The present work aimed to design, synthesize, and biologically evaluate a novel glucose-methotrexate conjugate (Glu-MTX). Our study showed that Glu-MTX exerts an increased cytotoxic effect on cancer cells in comparison to MTX in hypoxia $\left(1 \% \mathrm{O}_{2}\right)$ and glucose starvation conditions. Furthermore, Glu-MTX was found to inhibit the proliferation and migration of cancer cells more effectively than MTX does. Our results demonstrate that the conjugation of MTX to glucose led to an increase in potency against malignant cells under oxygen and nutrient stress. The observations shed light on a potential therapeutic approach to overcome chemoresistance in cancer.
\end{abstract}

Keywords: glycoconjugates; tumor microenvironment; methotrexate conjugate; hypoxia; cancer

\section{Introduction}

Chemotherapy is the leading treatment modality in oncological care and is commonly applied in combination with surgery or radiotherapy, depending on tumor advancement. During cancer progression, the tumor increases in size and triggers a series of events, including hypoxia and a nutrient-deficient environment [1]. These responses arise from the increase in oxygen and nutrient consumption due to significant growth of malignant proliferation, as well as an inadequate supply of substrates to the cells due to the formation of an irregular tumor microvasculature with leaky vessels [2]. An oxygen- and nutrientdeprived tumor microenvironment is considered a key mechanism responsible for cancer resistance to current treatment modalities, including chemotherapy, radiotherapy, and photodynamic therapy [3]. The critical role of hypoxia in chemotherapy resistance is welldocumented and involves several pathways, predominantly the upregulation of hypoxiainducible factor- $1 \alpha(\mathrm{HIF}-1 \alpha)$. The HIF- $1 \alpha$ mediates the angiogenesis, invasion, metastasis of malignant cells; induces glucose transporters (GLUT) to increase glucose import; and contributes to chemotherapy resistance by enhancing the expression of membrane efflux pump P-glycoprotein (P-gp), which identifies chemotherapeutic drugs and removes them from cells [4]. These events are among the primary contributors to multidrug resistance, 
which often results in cancer relapse and higher mortality [5]. Thus, breaking hypoxiainduced drug resistance is necessary to elevate the efficacy of cancer chemotherapy and increase the patient's lifespan.

To survive in an oxygen- and nutrient-deprived environment and address the energy demands resulting from rapid proliferation, tumor cells significantly increase glucose uptake and the flux of metabolites through glycolysis [6]. This metabolic shift, termed "the Warburg effect", is one of cancer's most common traits and provides clinically corroborated strategies for cancer diagnostics and treatment.

Chemotherapy is the leading treatment modality in oncological care and is commonly applied in combination with surgery or radiotherapy, depending on tumor advancement. The modification of biologically active compounds with polymers is one way to alter and control their pharmacokinetics, biodistribution, and often toxicity [7]. The primary underlying mechanism proposed for nanomedicine-based cancer therapy is passive targeting associated with enhanced permeability and retention [8]. To be most effective, anticancer drugs must penetrate tissue efficiently, reaching all the cancer cells that comprise the target population in a concentration sufficient to exert a therapeutic effect. The therapeutic effect of conjugates of biologically active compounds with polymers is reduced because of limited penetration [9].

Based on the overexpression of specific receptors on tumor cells, ligand-targeted drug delivery has been developed with the ability to efficiently deliver imaging agents in the tumor area or drugs into tumor cells via receptor-mediated endocytosis [10]. As mentioned above, elevated glucose intake and GLUT overexpression frequently occur in neoplasms and provide clinically corroborated strategies for cancer treatment [11-13]. Therefore, glycoconjugation, in which known cytotoxins or targeted anticancer therapeutics have been linked to glucose to improve cancer targeting and cellular selectivity, has become an appealing strategy for the targeted delivery of anticancer drugs [14,15]. These strategies employ the use of conjugates of D-glucose and bioactive molecule methotrexate (MTX) to improve efficacy and lower toxicity. MTX has been successfully used for many years in the treatment of patients with cancer and as an anti-inflammatory drug for the treatment of inflammatory diseases, such as rheumatoid arthritis.

There are many novel delivery systems that have been developed to improve the pitfalls of MTX therapy, ranging from polymeric conjugates, such as human serum albumin, liposomes, microspheres, solid lipid nanoparticles, polymeric nanoparticles, dendrimers, polymeric micelles, in situ forming hydrogels, and carrier erythrocyte, to nanotechnologybased vehicles such as carbon nanotubes, magnetic nanoparticles, and gold nanoparticles. Some of them are further modified with targeting ligands for active targeting purposes [16]. The pharmacokinetic properties of MTX polymeric conjugates are unsatisfactory because of their low penetration into cancer cells.

In the present work, we designed, synthesized, and biologically evaluated a novel glucose-methotrexate conjugate (Glu-MTX). Here, we investigated whether Glu-MTX could overcome MTX chemoresistance in oxygen and glucose-deprived cancer cells and the relative molecular mechanisms. This research aimed to assess the possibility of overcoming tumor microenvironment-induced drug resistance by conjugating a chemotherapeutic agent to glucose.

\section{Results}

\subsection{Chemistry}

When designing the synthesis of glycoconjugate derivatives of MTX, the following assumptions were made: glycoconjugate is selectively transferred to the cancer cell by GLUT proteins responsible for the transfer of D-glucose to tumor cells. To increase the water solubility of the prodrug and increase the affinity for GLUT transmembrane proteins, the conjugate contains two sugar units. The designed construct contains D-glucose linked via a linker to MTX. The key bonds connecting both molecules are susceptible to the action of hydrolytic enzymes, which allows the release of MTX, D-glucose, and the linker in the 
cell. D-glucose is connected to the linker via a $\beta$-glycosidic bond that is susceptible to hydrolysis catalyzed by glycoside hydrolases. On the other hand, MTX is connected to the linker by a carbamate bond formed with the participation of amino groups. The cleavable linkage allows the release of the cytotoxic payload inside the malignant cells, possibly through enzymatic hydrolysis. The critical step of connecting the D-glucose derivative to MTX is accomplished in the 1,3-dipolar cycloaddition of the azide to a terminal alkyne bond in a variant developed by Sharpless [17], which is a method widely used in the synthesis of biologically active compounds [18].

The ability of substituted glucose analogs to be substrates for GLUT-1 has been investigated $[19,20]$. Kinetic and computational modeling studies using glucose analogs suggest that the hydroxyl groups at positions 1 and 3 and the pyran oxygen in the D-glucose most thermodynamically stable conformation are involved in stabilizing hydrogen bonding interactions with amino acid residues within the transporter. The loss of hydrogen bond acceptors at these positions makes glucose analogs poor substrates for GLUT-1. Thus, these data suggest that for glucose conjugates to remain substrates for GLUT-1, compounds with hydrogen bond acceptors such as nitrogen or oxygen must be retained proximal to carbons 1 and 3, and substitutions at the C1 position may retain a higher affinity for GLUT-1 if they are present in an equatorial conformation. A large number of known glucose conjugates are conjugated to the anticancer agent at position 1, with the $\mathrm{C} 1$ oxygen intact and locked into the equatorial $\beta$-D-position [21,22].

Based on literature data, a synthesis of glycoconjugate was designed in which Dglucose via a linker is associated with the cytotoxic compound methotrexate (Figure 1).

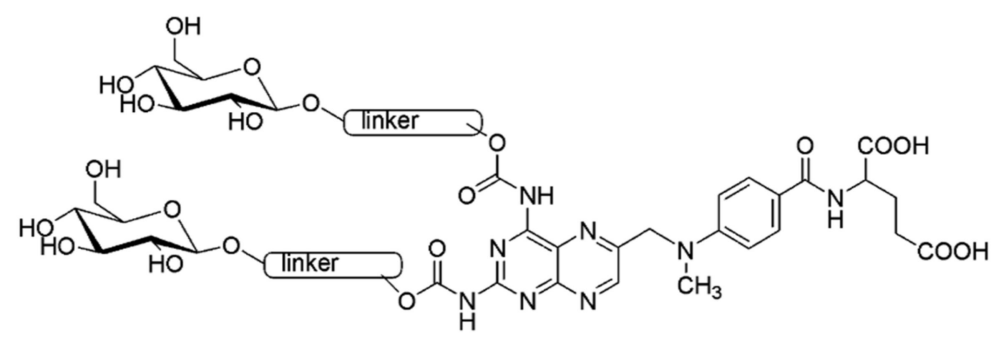

Figure 1. Structure of the MTX glycoconjugate (methotrexate glycoconjugate).

The sugar unit occurring in the most thermodynamically stable ${ }^{4} \mathrm{C}_{1}$ conformation is connected by the $\beta-O$-glycosyl bond with the spacer because, as is evident from the literature studies, such an orientation is preferred by the GLUT-1 transporting protein. The next fragment of the spacer contains the 1,2,3-triazine system because, as can be expected from the literature studies, the introduction of a functional group capable of hydrogen bonding increases the affinity of the compound to the transporting protein. The methotrexate is connected to the linker by forming a carbamate bond. After the introduction into the cell, the designed conjugate is susceptible to hydrolysis catalyzed by hydrolytic enzymes (glucosidases, peptidases) overexpressed in cancer cells following the release of a cytotoxic substance in the cancer target.

The coupling of two molecular components with different properties promises to generate a new conjugate with unprecedented biological activity, as different molecular segments can act together [23]. This perspective is a new, practically simple, and very reliable fast-growing approach for the development of pharmaceutically important druglike molecules that can accelerate drug discovery research for human use. Sharpless et al. [17] discussed the $\mathrm{Cu}(\mathrm{I})$-catalyzed azide-alkyne 1,3-dipolar cycloaddition ("click chemistry"), a set of powerful, selective, and reliable reactions for coupling molecular fragments under mild reaction conditions. The option to combine bioconjugation with click chemistry has emerged as a versatile tool with a wide range of applications. Effectively, the 1,2,3-triazole ring results in an ideal linker in bioconjugation, as (a) it presents a good water solubility, thus allowing in vivo administration; (b) it is analogous to an amide function for its electronic properties but is resistant to hydrolysis; (c) it is sufficiently stable in 
biological systems; and, finally, (d) it is a rigid linker, which allows internal interaction between the two linked moieties to be avoided. The unique features of click chemistry provide a toolbox for efficient coupling methodologies for the synthesis of a variety of conjugates $[18,24]$. Of the click reactions that have been developed, the most widely applied is the copper-catalyzed azide-alkyne cycloaddition reaction ( $\mathrm{CuAAC}$ ). Considering the advantages of this solution in our glycoconjugate synthesis project, a sugar unit containing a terminal azide group was combined with a propargyl carbamate-derived methotrexate. This convenient approach enables the rapid synthesis of carbohydrate conjugates in which the heterocyclic triazole ring serves as a shackle for joining the carbohydrate moiety to the biomolecule. When we move toward carbohydrate chemistry, the sugar moiety can be easily furnished with an azide functionality with routine synthetic protocols [25,26]. One of the substrates in the synthesis of glycoconjugate was the 2-azidoethyl $\beta$-D-glucopyranoside 1. It was obtained as $\beta$-glucoside in a coupling reaction between 2 -bromoethanol and $1,2,3,4,6$-penta- $O$-acetyl- $\beta$-D-glucose in the presence of boron trifluoride diethyl etherate $\left(\mathrm{BF}_{3} \cdot \mathrm{Et}_{2} \mathrm{O}\right)$ as a catalyst [26]. An azido function was introduced via the $\mathrm{S}_{\mathrm{N}} 2$ displacement of the bromine, using sodium azide in $N, N$-dimethylformamide (DMF) [25]. The last step was deprotection of the $O$-acetyl-protected glucoside under Zemplén conditions by the use of sodium methoxide in $\mathrm{MeOH}[25,27]$.

The second intermediate substrate is a derivative of methotrexate bearing a terminal acetylenic group. This synthesis was much more challenging. Such a group can be attached to methotrexate via an amide or a carbamate bond. Methotrexate is an unstable compound that is practically insoluble in organic solvents applied in the amidation reaction. A more convenient way to prepare amides could be the direct condensation of carboxylic acids and amines. Nevertheless, it is known that such an "ideal" amidation process needs very harsh conditions (temperature above $100^{\circ} \mathrm{C}$ ) to circumvent unreactive carboxylate-ammonium salts formation toward the desired amide bond formation [28]. This is adverse because other sensitive functionalities are present within coupled compounds. Therefore, the activation of carboxylic acid seems to be necessary [28]. The results of the conducted experiments associated with the selection of activation conditions are presented in Table 1.

Table 1. Adjusting the condensation reaction conditions.

\begin{tabular}{|c|c|c|c|c|c|c|}
\hline Procedure & Substrate 1 & Substrate 2 & Reagents & Solvent & $\begin{array}{l}\text { Reaction } \\
\text { Time [h] }\end{array}$ & Yield [\%] \\
\hline \multirow{3}{*}{ A } & \multirow{3}{*}{ MTX } & \multirow{3}{*}{ Propiolic acid } & DCC & DMF & \multirow{3}{*}{48} & traces \\
\hline & & & DCC/DMAP & DMF & & 12 \\
\hline & & & DCC/DMAP & $\mathrm{DMF} / \mathrm{CH}_{2} \mathrm{Cl}_{2}$ & & 18 \\
\hline \multirow{3}{*}{ B } & \multirow{3}{*}{ MTX } & \multirow{3}{*}{$\begin{array}{c}\text { Propargyl } \\
\text { chloroformate }\end{array}$} & Pyridine & \multirow{3}{*}{$\mathrm{DMF} / \mathrm{CH}_{2} \mathrm{Cl}_{2}$} & \multirow{3}{*}{24} & 22 \\
\hline & & & Triethylamine & & & inseparable \\
\hline & & & $\begin{array}{l}\text { DMAP } \\
\text { Imidazole }\end{array}$ & & & reaction mixture \\
\hline \multirow{6}{*}{$\mathrm{C}$} & \multirow{6}{*}{ MTX } & \multirow{6}{*}{$\begin{array}{c}\text { Propargyl } \\
\text { chloroformate }\end{array}$} & & $\mathrm{CHCl}_{3}$ & \multirow{6}{*}{24} & - \\
\hline & & & & THF & & 8 \\
\hline & & & N- & $\mathrm{CH}_{3} \mathrm{CN}$ & & 4 \\
\hline & & & Methylımidazole & $\mathrm{DMF} / \mathrm{CH}_{2} \mathrm{Cl}_{2}$ & & 21 \\
\hline & & & & $\mathrm{CH}_{2} \mathrm{Cl}_{2}$ & & 32 \\
\hline & & & NMI/Hünigs base & $\mathrm{CH}_{2} \mathrm{Cl}_{2}$ & & 42 \\
\hline
\end{tabular}

There are numerous commercially available coupling reagents for constructing an amide bond, including carbodiimides alone or plus additives such as HOBt or DMAP [29]. The carbodiimide reacts with the carboxylic acid to form $\mathrm{O}$-acylisourea mixed anhydride, which can react directly with an amine to yield the desired amide. We applied the DCC/DMAP condensing system for coupling propiolic acid with methotrexate. The reaction was carried out at room temperature for $48 \mathrm{~h}$ in different solvents. Unfortunately, the complex reaction mixture was formed, and the desired product was isolated in a poor 
yield. The low yield of the desired product induced us to search for another method of MTX functionalization. The reaction of acyl halides with an amino group is, in principle, the simplest approach to amide bond synthesis. Propargyl acid chlorides are unstable, and we choose the commercially available propargyl chloroformate. Such a reaction requires the presence of a tertiary amine in the reaction medium. A range of tertiary amines was tested; however, the reaction of MTX with propargyl chloroformate in the presence of a variety of organic bases such as pyridine, $\mathrm{Et}_{3} \mathrm{~N}, \mathrm{DMAP}$, and imidazole in several different solvents gave MTX derivatives in very low yields. The treatment of methotrexate with two equivalents of propargyl chloroformate and tertiary amine in $\mathrm{DMF} / \mathrm{CH}_{2} \mathrm{Cl}_{2}$ at room temperature gave the mixed anhydrides [29], which were condensed with amine groups of MTX, and an inseparable reaction mixture was obtained. An extremely effective acylating agent, 1-carboxybenzyl 3-ethylimidazol triethyloxonium tetrafluoroborate, was applied in the synthesis of nucleoside carbamates [30]. Assuming that an analogous acylating agent can be formed in a reaction of propargyl chloroformate 2 and $\mathrm{N}$-methylimidazole, this compound was selected in subsequent reactions. When $\mathrm{N}$-methylimidazole (NMI) was used, the yield of the desired carbamate derivative of MTX 4 was significantly improved depending on the solvent (DMF, $\mathrm{CH}_{2} \mathrm{Cl}_{2}, \mathrm{CH}_{3} \mathrm{CN}$, THF, $\mathrm{CHCl}_{3}$ ). The optimal yield of 4 was obtained in the reaction with four molar equivalents of compound 2 in the presence of eight molar equivalents of NMI and tertiary amine ( $N, N$-diisopropylethylamine) in methylene chloride, which was carried out for $24 \mathrm{~h}$ at room temperature (Scheme 1).

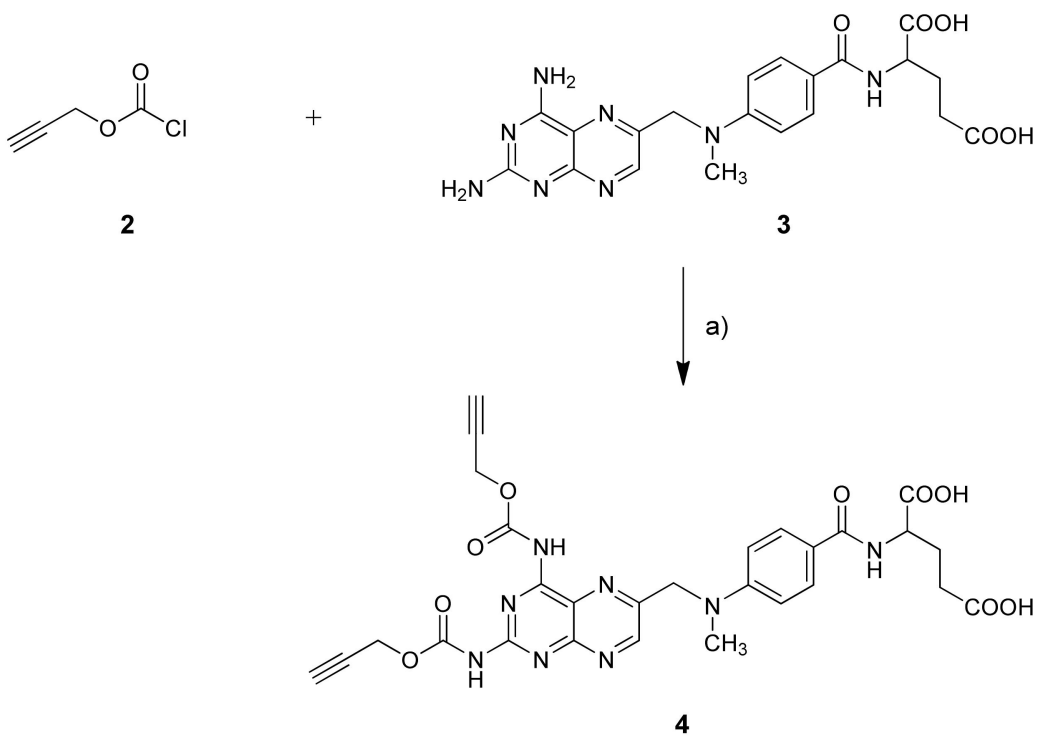

a) $\mathrm{N}$-Methylimidazole, $\mathrm{N}, \mathrm{N}$-diisopropylethylamine, methylene chloride, r.t., $24 \mathrm{~h}$

Scheme 1. Functionalization of methotrexate.

The structure of the obtained product 4 was elucidated by ${ }^{1} \mathrm{H}$ and ${ }^{13} \mathrm{C}$ NMR data. This product was assigned as the propargyl carbamate. According to ${ }^{13} \mathrm{C}$ NMR spectra, the acetylene carbon $(77.73,78.47 \mathrm{ppm})$ and carbamate carbon signals $(165.61 \mathrm{ppm})$ were still present, indicating that the acylation of amines took place. This compound has been used as a scaffold for the synthesis of multivalent carbohydrate conjugates (Scheme 2).

Methotrexate intermediate derivative 4 is an unstable compound that is practically insoluble in water and typical solvents applied in the copper-catalyzed azide-alkyne cycloaddition reaction (CuAAC) $[17,18,24]$. For this reason, a series of experiments adjusting the $\mathrm{CuAAC}$ reaction conditions were performed (Table 2). 


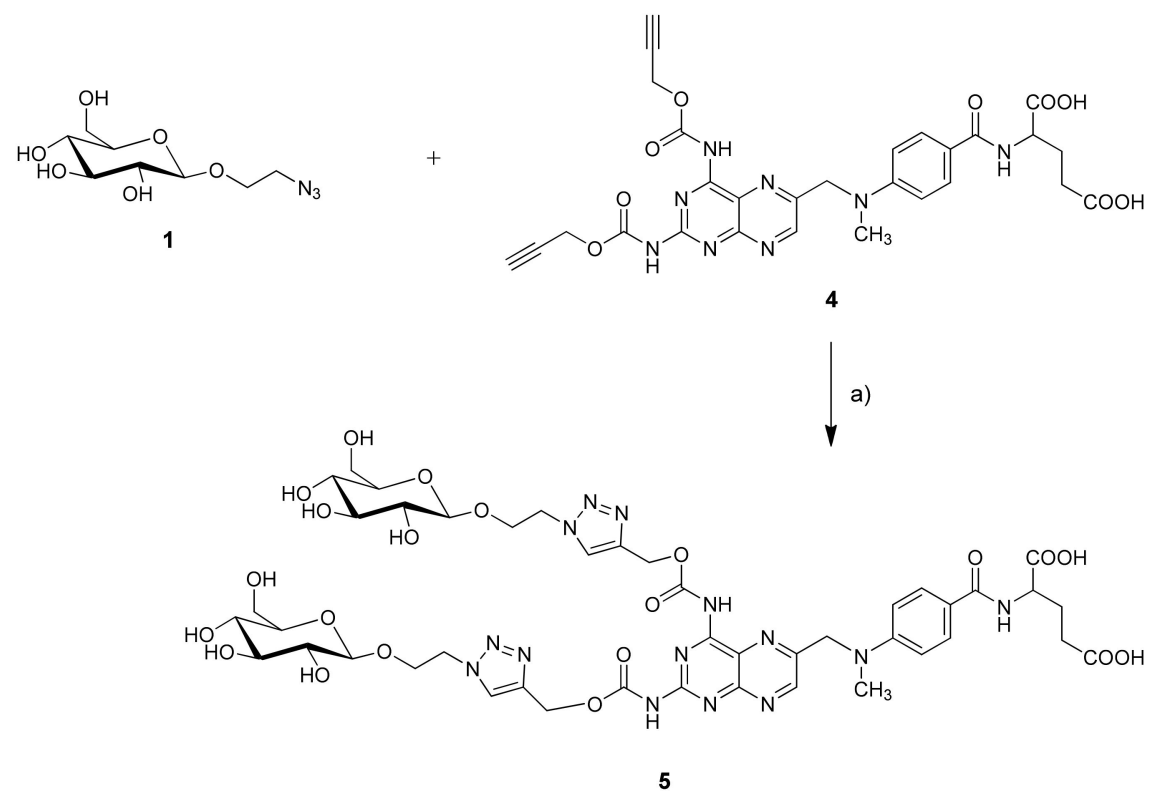

a) $\mathrm{CuSO}_{4} 5 \mathrm{H}_{2} \mathrm{O}$, sodium ascorbate, $\mathrm{H}_{2} \mathrm{O} / \mathrm{THF} / \mathrm{i}-\mathrm{PrOH} / \mathrm{N}, N$-diisopropylethylamine, r.t., $24 \mathrm{~h}$

Scheme 2. Synthesis of glycoconjugate Glu-MTX.

Table 2. Adjusting the CuAAC reaction conditions (copper catalyzed azido-alkyne cycloaddition).

\begin{tabular}{ccccccc}
\hline Procedure & Substrate 1 & Substrate 2 & Catalyst & Solvent & Reaction Time [h] & Yield [\%] \\
\hline $\mathrm{A}$ & 1 & 4 & $\mathrm{NaAsc} / \mathrm{CuSO} \cdot 5 \mathrm{H}_{2} \mathrm{O}$ & $\mathrm{THF} / i-\mathrm{PrOH} / \mathrm{H}_{2} \mathrm{O}$ & 24 & 11 \\
$\mathrm{~B}$ & 1 & 4 & $\mathrm{NaAsc} / \mathrm{CuSO} \cdot 5 \mathrm{H}_{2} \mathrm{O}$ & $\begin{array}{c}\mathrm{THF} / i-\mathrm{PrOH} / \mathrm{H}_{2} \mathrm{O} \\
\mathrm{NaOH}\end{array}$ & 24 \\
\hline $\mathrm{C}$ & 1 & 4 & $\mathrm{NaAsc} / \mathrm{CuSO}_{4} \cdot 5 \mathrm{H}_{2} \mathrm{O}$ & $\begin{array}{c}\mathrm{THF} / i-\mathrm{PrOH} / \mathrm{H}_{2} \mathrm{O} \\
\text { Hünig's base }\end{array}$ & 24 & 77 \\
\hline
\end{tabular}

The conventional $\mathrm{Cu}(\mathrm{I})$-catalyzed coupling of $\mathbf{4}$ with glucosyl azide $\mathbf{1}$ afforded the desired product in low yields (11\%). The low yield of glycoconjugate induced us to search for a better procedure of conjugation. As it turned out, copper(I)-catalyzed cycloaddition exclusively transformed substrates into the 1,2,3-triazole conjugate with the best yield $(77 \%)$ by the treatment of sugar azide 1 with a solution of MTX carbamate 4 in the mixture of $\mathrm{THF} / i-\mathrm{PrOH} / \mathrm{H}_{2} \mathrm{O}$ with the addition of $\mathrm{N}, \mathrm{N}$-diisopropylethylamine under sonification (Scheme 2).

Glycoconjugate 5 was purified by column chromatography, and its structure was elucidated by ${ }^{1} \mathrm{H}$ and ${ }^{13} \mathrm{C}$ NMR data and mass spectrometry analysis. The NMR analyses were in full agreement with the expected structure (see the Supporting Information). ${ }^{1} \mathrm{H}$ NMR and coupling constants unambiguously confirmed $\beta$-configurations at the anomeric centers of the pyranose units. The remarkably well-resolved NMR peaks indicated that the glycoconjugate exhibited only marginal aggregation behavior in the DMSO solution.

Additionally, we have performed a mass spectrometry analysis, which indicated that within $4 \mathrm{~h}$ after the administration of the conjugate to the culture medium, the compound did not undergo degradation and entered the cells and released the cytotoxic payload (MTX) (Figure S1). However, we did not find other high molecular weight products (such as triazole or the linker) in the intracellular compartment, which suggests that the sugar moiety of the conjugate is quickly degraded after the internalization of the compound. 


\subsection{Biology Experiments}

2.2.1. Glu-MTX Compared to MTX Exerted More Potent Cytotoxic Activity on MCF-7 and SW480 Cancer Cell Lines in Hypoxia and Glucose-Deprived Microenvironment

To investigate the effect of hypoxia on the MTX chemotherapy sensitivity, MCF-7 and SW480 cells in a controlled normoxia environment and a controlled hypoxia environment were relatively exposed to the various concentrations of MTX $(5 \sim 20 \mu \mathrm{M})$ for $48 \mathrm{~h}$. Compared with MCF-7/normoxia, the cell viability (\%) in MCF-7/hypoxia decreases by $30 \%$ at the MTX dosage of $20 \mu \mathrm{M}$ (Figure 2A). The same was observed for SW480 cells, where the viability (\%) in normoxic cells was $29 \%$ lower than in hypoxic cells (Figure 2B). These findings indicate that hypoxia induces MTX chemoresistance. To investigate whether glucose and methotrexate conjugation could overcome hypoxia-induced drug resistance, we treated MCF-7 and SW480 cells in a controlled hypoxia environment with Glu-MTX for $48 \mathrm{~h}$. Glu-MTX exerted a significantly stronger cytotoxic effect compared to MTX in hypoxic conditions. The $\mathrm{IC}_{50}$ of Glu-MTX was $\sim 10 \mu \mathrm{M}$ in both cell lines (Figure 2A,B). Compared to MTX, Glu-MTX at a dose of $20 \mu \mathrm{M}$ exerted a 2.3 times greater cytotoxic effect on cancer cells in a hypoxic microenvironment.

To assess the effect of Glu-MTX in glucose-deprived cells, which were slightly more resistant to MTX than regular cells, we treated MCF-7 and SW480 cells in a controlled glucose-deprived environment with MTX and Glu-MTX for $48 \mathrm{~h}$. The effect of glucose starvation on the MTX chemotherapy sensitivity was assessed in MCF-7 and SW480 cells in a controlled glucose-rich environment and controlled glucose-deprived environment. The cells were exposed to various concentrations of MTX $(5 \sim 20 \mu \mathrm{M})$ for $48 \mathrm{~h}$. Compared with MCF-7 cultured with glucose medium, the cell viability (\%) of MCF-7 without glucose decreases by $17 \%$ at the Glu-MTX dosage of $20 \mu \mathrm{M}$ (Figure 2C), whereas in SW480 cells, the viability (\%) in glucose-rich cells was nearly $24 \%$ higher than in glucose-deprived cells at the Glu-MTX dosage of $20 \mu \mathrm{M}$ (Figure 2D). These findings prove that glucose starvation affects the susceptibility of cancer cells to Glu-MTX and indicate the greater efficacy of Glu-MTX compared to MTX in glucose-deprived conditions.

To examine the effect of Glu-MTX in the tumor microenvironment, which comprises hypoxia and glucose-deprived medium, we treated MCF-7 and SW480 cells in the controlled hypoxia and glucose-deprived environment with MTX and Glu-MTX for $48 \mathrm{~h}$. Both cancer cell lines were resistant to MTX (cell viability 74\% for MCF-7 and 80\% for SW480) even at a high dose of $20 \mu \mathrm{M}$, whereas, at the same dose, the cytotoxic effect of Glu-MTX was significantly higher (cell viability $33 \%$ for MCF-7 and $23 \%$ for SW480). The $\mathrm{IC}_{50}$ of Glu-MTX in the tumor microenvironment was in the range of $4 \sim 4.5 \mu \mathrm{M}$ for both cell lines (Figure 2E).

\subsubsection{Glu-MTX Inhibits the Wound Healing Process}

Since the hypoxic breast and colon cancer cells could have altered migration behavior in response to different cytotoxic agents, we furthermore examined the effect of MTX and Glu-MTX on these parameters using in vitro wound-healing assay. The assay examines the migration of cells by evaluating the closure of a standard scratch in time. In both cancer cell lines, we found that Glu-MTX-treated cells had significantly slower migration than MTX-treated cells. At $48 \mathrm{~h}$, the wound was unclosed in Glu-MTX-treated cells, whereas in MTX-treated cells, the gap was considerably smaller (Figure 3A,B).

\subsubsection{Glu-MTX Induces Apoptosis by Increasing the Expression of Caspase-3 and Bax}

The expression of proapoptotic proteins - caspase 3 and Bax in SW480/hypoxia cellswas analyzed by immunocytochemistry (Figure 4). We detected high levels of proapoptotic proteins (bax and caspase-3) in cells treated with Glu-MTX and MTX compared to the control. The intensity and percentage positivity of staining were similar or slightly elevated in Glu-MTX-treated cells compared to in MTX-treated cells. 

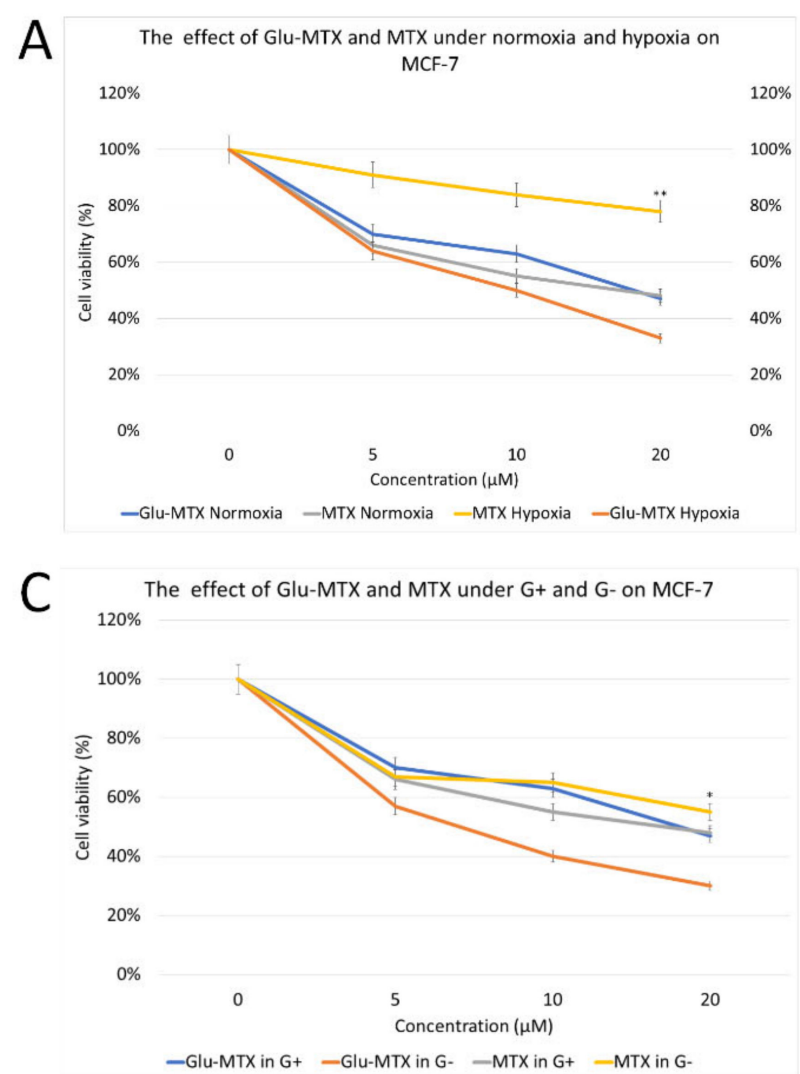

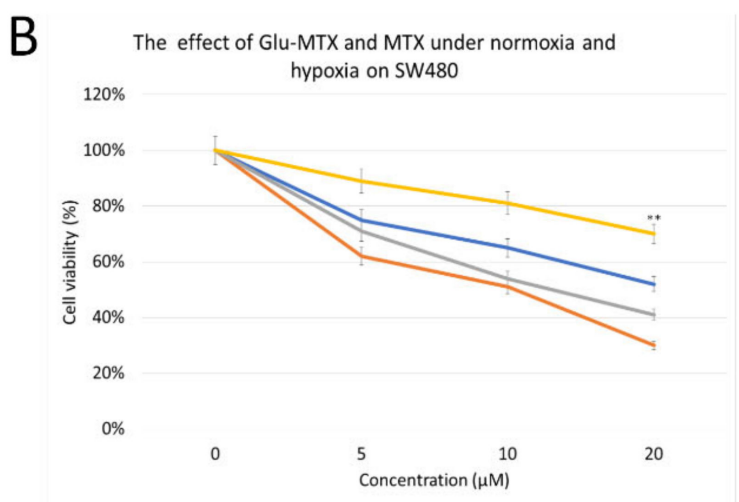

-Glu-MTX Normoxia -Glu-MTX Hypoxia - MTX Normoxia - MTX Hypoxia

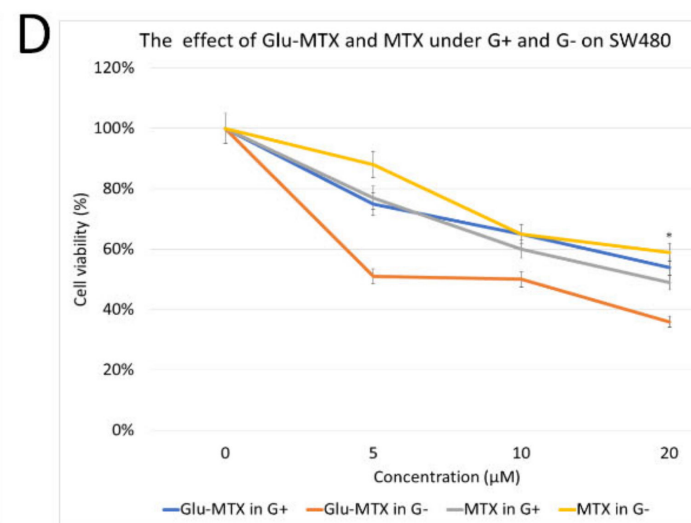

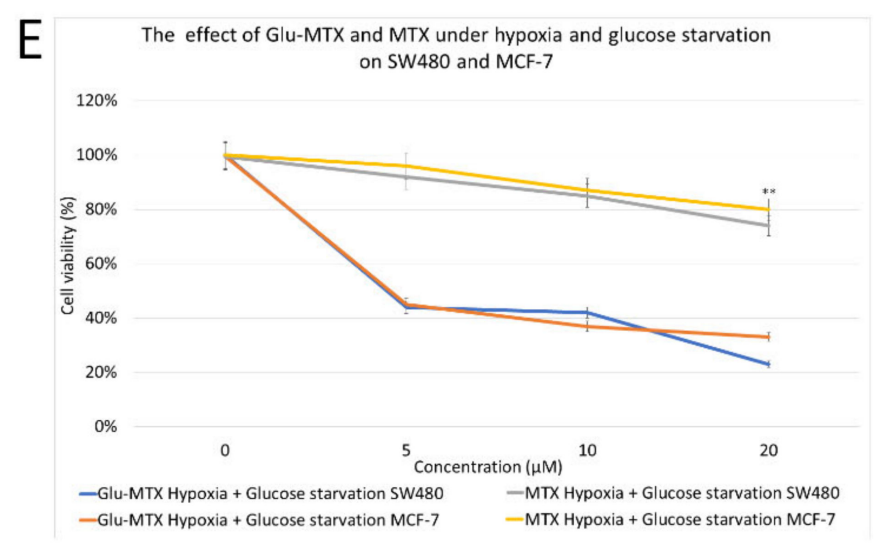

Figure 2. Results of cell viability after $48 \mathrm{~h}$ of incubation with $0,5,10,20 \mu \mathrm{M}$ of MTX and Glu-MTX evaluated by MTT assay. (A) Dose-dependency curves for MCF-7 cells in normoxic ( $21 \%$ of oxygen, $\left.5 \% \mathrm{CO}_{2}\right)$ and hypoxic ( $1 \%$ of oxygen, $\left.5 \% \mathrm{CO}_{2}\right)$ conditions. (B) Dose-dependency curves for SW480 cells in normoxic ( $21 \%$ of oxygen, $\left.5 \% \mathrm{CO}_{2}\right)$ and hypoxic ( $1 \%$ of oxygen, $5 \% \mathrm{CO}_{2}$ ) conditions. (C) Dose-dependency curves for MCF-7 cells cultured in medium with glucose (G+) and glucose-free medium (G-). (D) Dose-dependency curves for SW480 cells cultured in medium with glucose (G+) and glucose-free medium (G-). (E) Dose-dependency curves for MCF-7 and SW480 cells in normal culture conditions ( $21 \%$ of oxygen, $5 \% \mathrm{CO}_{2}, \mathrm{G}+$ ) and in hypoxic ( $1 \%$ of oxygen, $\left.5 \% \mathrm{CO}_{2}\right)$ with glucose starvation conditions $(\mathrm{G}-$ ). Data are expressed as mean \pm SD from triplicates. ${ }^{*} p<0.05,{ }^{* *} p<0.01$, comparing Glu-MTX with MTX in hypoxia and/or glucose starvation conditions.

The flow cytometry analysis results are shown in Figure 5. The flow cytometry analysis results are shown in Figure 5. In comparison to the SW80 cells treated with MTX, Glu-MTX in hypoxic conditions presents increased late apoptosis after the proposed treatment. We have observed increased effectiveness of early and late apoptosis induction in almost 25\% of cells after treatment with Glu-MTX (44\%) in comparison to free MTX (19\%). Control cells and MTX-treated cells demonstrate a similar rate of apoptosis induction and reveal decreased MTX potency in hypoxia. 
A

Control

MTX

Glu-MTX
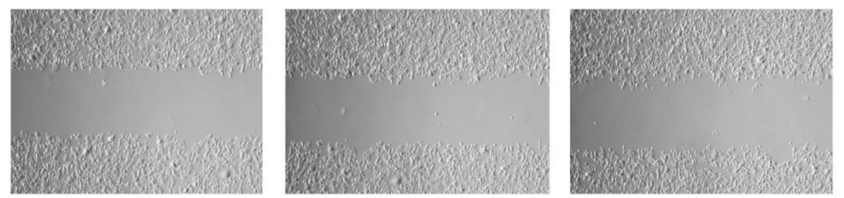

Oh
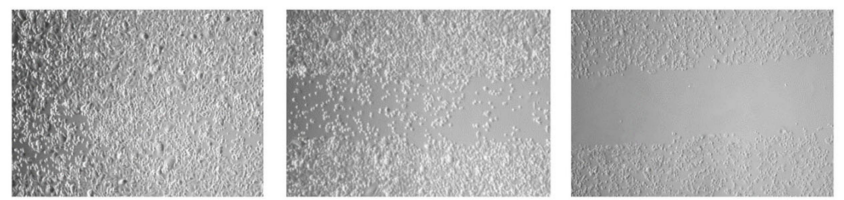

$48 \mathrm{~h}$

B
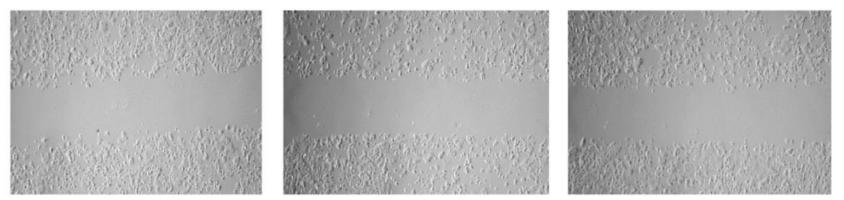

Oh
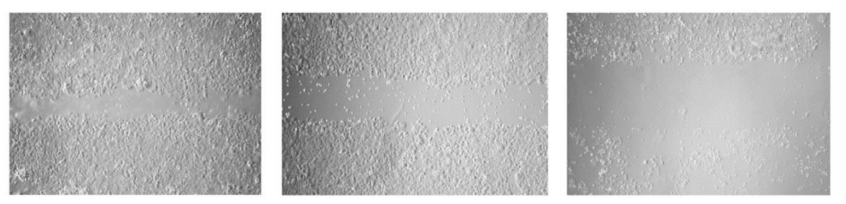

$48 \mathrm{~h}$

Figure 3. Wound-healing assay at time point 0 and after $48 \mathrm{~h}$ of incubation with $10 \mu \mathrm{M}$ of MTX and Glu-MTX. Results show that after $48 \mathrm{~h}$, the scrap in control cells is fully coated by cells, whereas in MTX-treated samples, the scrap is smaller compared to samples incubated with Glu-MTX, where no migration of cells is observed. (A) Representative images of SW480 cells. (B) Representative images of MCF-7 cells. $10 \times$ objectives were used to capture the photographs.

Control
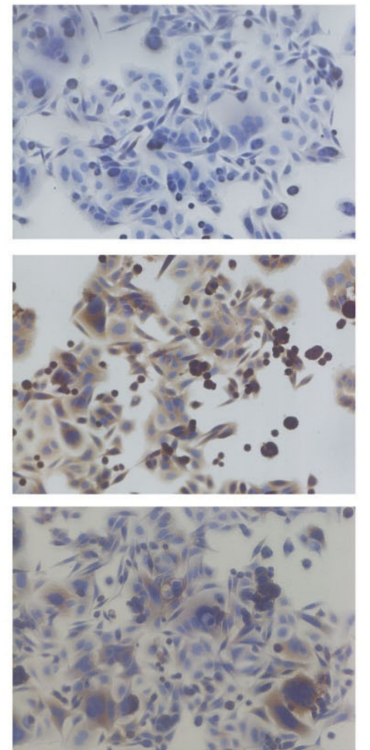

MTX
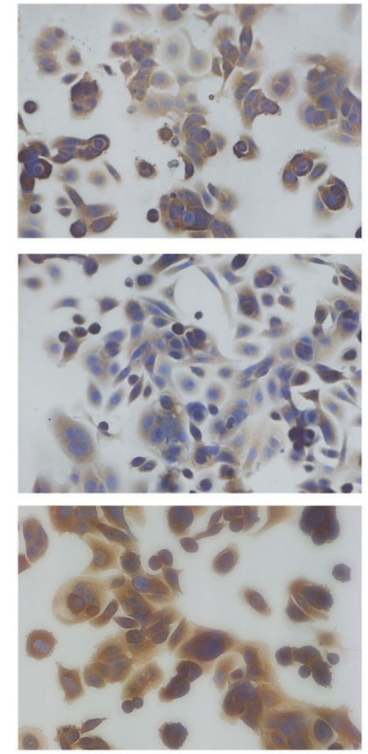

Glu-MTX

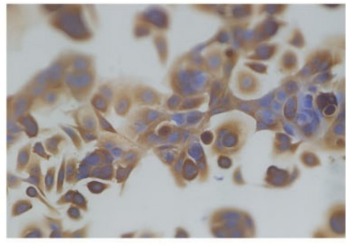

bax

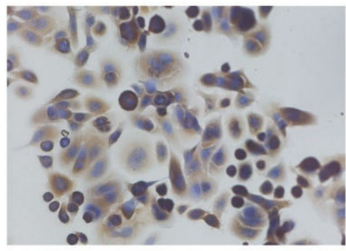

bcl-2

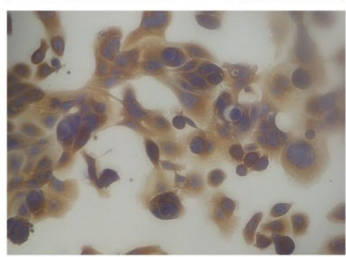

Figure 4. Representative images of the immunocytochemical analysis of bax, bcl-2, and caspase 3 apoptosis-related proteins in the SW480 cell line in control, treated with $10 \mu \mathrm{M}$ of MTX and Glu-MTX samples after $48 \mathrm{~h}$. $20 \times$ and $40 \times$ objectives were used to capture the photographs. 


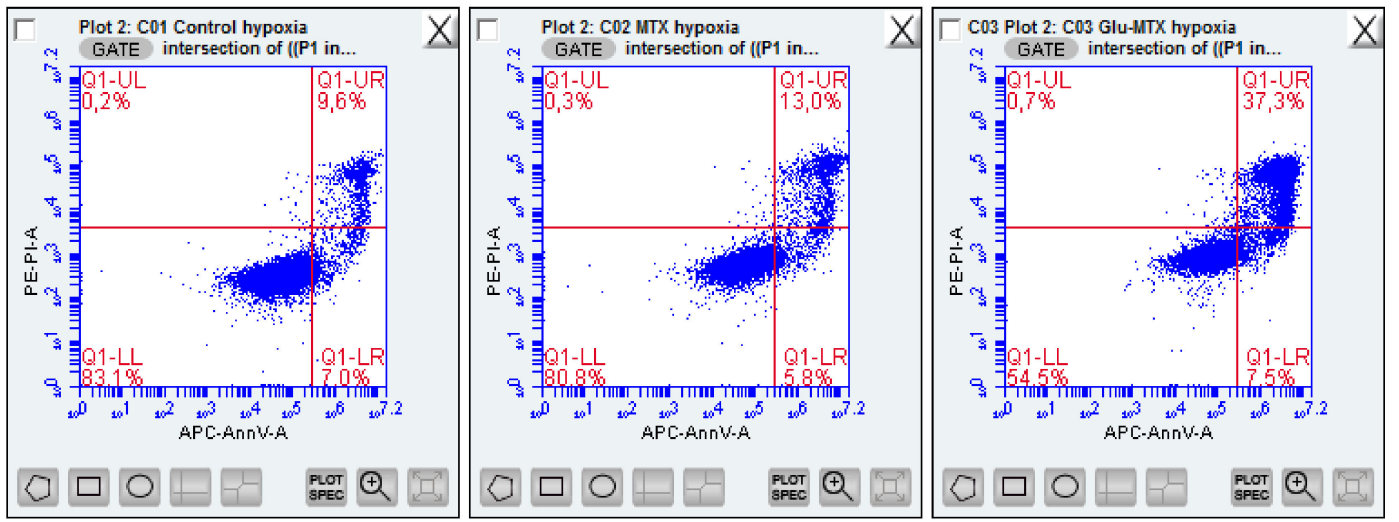

Figure 5. Results demonstrate representative images of flow cytometry analysis of viable (LL-lower left), early (LR-lower right), late (UR-upper right) apoptotic, and dead (UL-upper left) MCF-7 cells after incubation with $10 \mu \mathrm{M}$ of MTX and Glu-MTX for $48 \mathrm{~h}$ in the tumor microenvironment in comparison to the control group without any treatment. All the samples were prepared using an Annexin V-FITC and PI Apoptosis Detection Kit (Abcam) and analyzed using a FACS Calibur flow cytometer (Beckton Dickinson, NJ, USA).

\section{Discussion}

Cancer cells' ability to evade or to handle the presence of chemotherapeutic agents is a fundamental challenge that oncology research aims to elucidate and overcome. Chemoresistance and malignant progression are closely linked with the tumor microenvironment, contributing to tumors' response to different therapeutic modalities [31,32]. The cancer microenvironment comprises many components, including extracellular matrix proteins, cancer-associated cells, and an aberrant vasculature. These physical elements give rise to the distinctive environmental properties of hypoxia and nutrient stress that inhibit the effect of cancer treatments [32]. The undesirable impact of hypoxia on malignancies relative to radio- and chemotherapy effectiveness has been established for several decades, and the survival rate of cancer patients with severely hypoxic tumors is shorter than that of patients with normoxic tumors [33].

Our study used a controlled hypoxia condition to assess the effectiveness of methotrexate on breast and colon cancer cells. We found that hypoxic cells were significantly more resistant to methotrexate than normoxic cells. These findings are consistent with previously published studies that found that hypoxia increased the resistance to methotrexate in various cancer types, including breast cancer, melanoma, and leukemia [34-36]. A study by $\mathrm{Li}$ et al. indicated that the HIF- $1 \alpha$-mediated pathway played a critical role in the susceptibility of MCF-7 breast cancer cells to methotrexate [34]. Due to the increasing evidence suggesting the role of nutrient stress, particularly glucose deprivation, in tumor cell survival, angiogenesis, and drug resistance, we assessed the effectiveness of methotrexate on glucose-deprived cancer cells [37-39]. We found that glucose-deficient cells were marginally less susceptible to methotrexate than regular cells.

We hypothesized that the linking of methotrexate to glucose could overcome the hypoxia- and/or nutrient stress-induced chemoresistance. The novel glycoconjugate of glucose and methotrexate exerted a strong and dose-dependent cytotoxic effect on hypoxic breast and colon cancer cells, which was nearly nine-fold more potent than MTX. Similarly, in a controlled glucose-deficient state, Glu-MTX displayed up to a three-fold enhanced cytotoxic effect in both cancer cell lines compared to MTX. As cancer cells consume glucose rampantly and given that glycolysis generates energy inefficiently, we hypothesize that GluMTX treatment under glucose starvation resulted in the potentiated cellular accumulation of the drug and thus resulted in an enhancement of cytotoxicity in tumor cells.

We cannot unequivocally state that the conjugate enters the cell specifically via the GLUT 1 transporter; however, given that the glycoconjugates are highly hydrophilic, they are unlikely to be internalized via passive diffusion through the lipid cell membrane. The accumulating evidence suggests that the cellular uptake of glycoconjugates must 
be mediated by transmembrane transporters. GLUTs are the most frequent transporters facilitating the recognition and internalization of glycoconjugates. However, we must emphasize that the transport capability of GLUTs can be slightly influenced by complex factors, such as the structure and the substitution position of the carbohydrate, the length and steric hindrance of linkers, and the property of the payload. The past evidence suggests that the cellular uptake of some glycoconjugates is not mediated solely by GLUT but also by other receptors such as OCT2 [40]. Moreover, the potential role of other transporters such as SGLT, SWEET, and ASGPR (asialoglycoprotein receptor) should also be considered [41].

In the present study, we found an intriguing fact that in the tumor microenvironment, comprising hypoxia and glucose deprivation, MTX did not exert a cytotoxic effect on cancer cells. However, the conjugation of glucose to methotrexate allowed us to overcome the resistance and to achieve a potent, dose-dependent anticancer effect. Moreover, our studies revealed that the Glu-MTX inhibited hypoxic cells' cell migration process more effectively than MTX did. The results confirmed that Glu-MTX-treated cells expressed high levels of antiapoptotic proteins and underwent apoptosis.

Mounting evidence suggests that the expression of GLUTs is upregulated in many cancers under hypoxia and nutrient stress by key pro-survival pathways, including the HIF and AMP-activated protein kinase (AMPK) pathways [42,43]. This may explain our findings that Glu-MTX was significantly more potent in a hypoxic and/or glucose-deprived environment than MTX.

\section{Materials and Methods}

\subsection{Chemistry}

NMR spectra were recorded on an Agilent spectrometer $400 \mathrm{MHz}$ (Agilent Technologies, Santa Clara, CA, USA) using TMS as an internal standard and $\mathrm{CDCl}_{3}$ or DMSO as a solvent. NMR solvents were purchased from ACROS Organics (Geel, Belgium). Chemical shifts $(\delta)$ are expressed in ppm and coupling constants $(J)$ in Hz. Optical rotations were measured with a JASCO 2000 polarimeter (JASCO Corporation, Tokyo, Japan) using a sodium lamp $(589.3 \mathrm{~nm})$ at room temperature. Melting point measurements were performed on a Stanford Research Systems OptiMelt (MPA 100) (Stanford Research System, Sunnyvale, CA, USA). Electrospray-ionization mass spectrometry was performed on a Xevo G2 Q-TOF mass spectrometer (Waters Chromatography, Etten-Leur, The Netherlands). Reactions were monitored by TLC on precoated plates of silica gel 60 F254 (Merck, Darmstadt, Deutschland). TLC plates were inspected under UV light $(\lambda=254 \mathrm{~nm})$ or charring after spraying with $10 \%$ sulfuric acid in ethanol. Crude products were purified using column chromatography performed on silica gel 60 (Fluka, Honeywell, NJ, USA) developed with toluene/EtOAc and $\mathrm{CHCl}_{3} / \mathrm{MeOH}$ as solvent systems. Organic solvents were evaporated on a rotary evaporator under diminished pressure at $40^{\circ} \mathrm{C}$.

All of the chemicals used in the experiments were purchased from Sigma-Aldrich (Saint Louis, MO, USA), ACROS Organics (Geel, Belgium), and Avantor Performance Materials Poland S.A (Gliwice, Poland) and were used without purification. Methotrexate 3, propargyl chloroformate 2, 2-bromoethanol, and D-glucose are commercially available. 1,2,3,4,6-Penta-O-acetyl- $\beta$-D-glucopyranose [44], 2-bromoethyl 2,3,4,6-tetra-O-acetyl- $\beta$-Dglucopyranoside [26], 2-azidoethyl 2,3,4,6-tetra-O-acetyl- $\beta$-D-glucopyranoside [25], and 2-azidoethyl $\beta$-D-glucopyranoside $\mathbf{1}[25,27]$ were prepared according to the respective published procedures.

\subsubsection{Synthesis of Carbamate 4}

Methotrexate 3 ( $227 \mathrm{mg}, 0.5 \mathrm{mmol}), \mathrm{N}$-methylimidazole ( $320 \mu \mathrm{L}, 4 \mathrm{mmol})$, and $\mathrm{N}, \mathrm{N}$ diisopropylethylamine $(165 \mu \mathrm{L}, 1 \mathrm{mmol})$ were sonicated for $30 \mathrm{~min}$. The mixture was cooled in ice water, and the solution of propargyl chloroformate $2(195 \mu \mathrm{L}, 2 \mathrm{mmol})$ in methylene chloride $(1 \mathrm{~mL})$ was added. The reaction mixture was stirred for $24 \mathrm{~h}$ at ambient temperature and then poured into ice water. The crude product was precipitated with acetic acid, filtered, washed with water, and drying under reduced pressure left a residue 
that was column chromatographed to yield bis-propargyl carbamate 4 ( $130 \mathrm{mg}$, $42 \%$ yield): m.p. $174-176^{\circ} \mathrm{C} ;[\alpha]_{\mathrm{D}}{ }^{23}=-2(c=1.0, \mathrm{DMSO})$.

${ }^{1} \mathrm{H}$ NMR (400 MHz, DMSO-d6): $\delta$ 1.85-2.16 (m, 2H, 2xCHMTX), 2.32 (m, 1H, CHMTX), $2.45(\mathrm{~m}, 1 \mathrm{H}, \mathrm{CHMTX}), 3.21\left(\mathrm{~s}, 3 \mathrm{H}, \mathrm{CH}_{3} \mathrm{MTX}\right), 3.52(\mathrm{~m}, 2 \mathrm{H}, 2 \mathrm{xCH}), 3.71\left(\mathrm{~s}, 2 \mathrm{H}, \mathrm{CH}_{2}\right), 4.35(\mathrm{~m}$, 1H, CHMTX), 4.62-4.72 (m, 2H, $\left.\mathrm{CH}_{2}\right), 4.80$ (s, 2H, $\left.\mathrm{CH}_{2} \mathrm{MTX}\right), 6.80-6.85$ (m, 2H, H-PhMTX), $7.12(\mathrm{~s}, 1 \mathrm{H}, \mathrm{NH}), 7.28$ (s, 1H, NH), 7.68-7.76 (m, 2H, H-PhMTX), 8.60 (m, 1H, NHMTX), $8.61(\mathrm{~s}, 1 \mathrm{H}, \mathrm{H}-7 \mathrm{MTX})$.

${ }^{13} \mathrm{C}$ NMR (100 MHz, DMSO-d6): $\delta$ 25.31, 29.39, 32.88, 50.89, 50.97, 51.03, 54.14, 76.93, 77.73, 78.47, 110.36, 120.41, 120.46, 128.23, 146.26, 148.39, 150.20, 152.65, 160.80, 161.99, $165.61,165.64,170.95,173.01,173.18$.

\subsubsection{Synthesis of Glycoconjugate 5}

Carbamate 4 (62 mg, $0.1 \mathrm{mmol}$ ) and azidoethyl glucoside 1 (50 mg, $0.2 \mathrm{mmol})$ were dissolved in dry $i$-PrOH $(2 \mathrm{~mL})$, THF $(2 \mathrm{~mL})$ and $N, N$-diisopropylethylamine $(60 \mu \mathrm{L}$, $0.36 \mathrm{mmol})$. The solutions of sodium ascorbate $(8 \mathrm{mg}, 0.04 \mathrm{mmol})$ in water $(1 \mathrm{~mL})$ and $\mathrm{CuSO}_{4} \cdot 5 \mathrm{H}_{2} \mathrm{O}(5 \mathrm{mg}, 0.02 \mathrm{mmol})$ in water $(2 \mathrm{~mL})$ were mixed and added to the reaction mixture and next stirred for $24 \mathrm{~h}$ at room temperature. The reaction mixture was filtered, the precipitate was washed with methyl alcohol, the combined filtrate was treated with acetic acid, and the crude product was separated by filtration, then washed, dried, and purified by column chromatography to yield glycoconjugate 5 ( $86 \mathrm{mg}, 77 \%$ yield): m.p. $175-177^{\circ} \mathrm{C} ;[\alpha]_{\mathrm{D}}^{22}=-20(c=1.0, \mathrm{DMSO})$.

${ }^{1} \mathrm{H}$ NMR (400 MHz, DMSO-d $\left.\mathrm{d}_{6}\right): \delta 1.71-2.10(\mathrm{~m}, 2 \mathrm{H}, 2 \times \mathrm{CHMTX}), 2.19-2.39(\mathrm{~m}, 2 \mathrm{H}$, 2xCHMTX), $2.96\left(\mathrm{dd}, 2 \mathrm{H}, J=7.8 \mathrm{~Hz}, J=8.6 \mathrm{~Hz}, \mathrm{H}-2_{\mathrm{Glu}}\right), 3.03(\mathrm{dd}, 2 \mathrm{H}, J=9.0 \mathrm{~Hz}, J=9.4 \mathrm{~Hz}$, $\left.\mathrm{H} 4_{\mathrm{Glu}}\right)$, 3.09-3.55 (m, 9H, CH 3 MTX, H-3 $\left.{ }_{\mathrm{Glu}}, \mathrm{H}-5_{\mathrm{Glu}}, \mathrm{H}-6 \mathrm{a}_{\mathrm{Glu}}\right), 3.63-3.79(\mathrm{~m}, 4 \mathrm{H}, 4 \times \mathrm{CCH})$, $3.68\left(\mathrm{dd}, 2 \mathrm{H}, J=1.6 \mathrm{~Hz}, J=11.4 \mathrm{~Hz}, \mathrm{H}-6 \mathrm{~b}_{\mathrm{Glu}}\right), 3.86-3.95(\mathrm{~m}, 2 \mathrm{H}, 2 \mathrm{CCH}), 4.01-4.12(\mathrm{~m}, 2 \mathrm{H}$, $2 \times \mathrm{CH}), 4.22\left(\mathrm{~d}, 2 \mathrm{H}, J=7.8 \mathrm{~Hz}, \mathrm{H}-1_{\mathrm{Glu}}\right), 4.29(\mathrm{~m}, 1 \mathrm{H}, \mathrm{CHMTX}), 4.55-4.61\left(\mathrm{~m}, 4 \mathrm{H}, 2 \mathrm{CCH}_{2}\right)$, 4.79 (bs, 2H, OH), 5.21 (s, 2H, CH $\left.{ }_{2} \mathrm{MTX}\right), 6.80-6.87$ (m, 2H, H-PhMTX), 7.66-7.72 (m, 2H, H-PhMTX), 7.95 (d, 1H, J = 7.0 Hz, NHMTX), 8.25 (s, 2H, H-5 triaz), 8.61 (s, 1H, H-7MTX).

${ }^{13} \mathrm{C}$ NMR $\left(100 \mathrm{MHz}, \mathrm{DMSO}-\mathrm{d}_{6}\right): \delta 24.62,30.33,31.64,48.55,49.72,54.87,60.62,61.05$, $67.19,69.99,73.26,76.54,76.95,102.87,111.09,121.49,125.84,128.62,140.91,146.75,149.15$, $150.83,154.04,163.78,165.39,165.56,173.56,174.26$. 1161.3710.

HRMS (ESI-TOF): calcd for $\mathrm{C}_{44} \mathrm{H}_{55} \mathrm{~N}_{14} \mathrm{O}_{21} \mathrm{Na}_{2}\left([\mathrm{M}+\mathrm{H}]^{+}\right): m / z$ 1161.3462; found $m / z$

\subsubsection{LC/MS Analysis}

UPLC analysis was performed on a Waters HSS T3 column $(1.7 \mu \mathrm{m}, 1 \times 50 \mathrm{~mm})$ using an Acquity UPLC system (Waters, Milford, MA, USA). The mobile phase consisted of $0.1 \%$ formic acid in water (mobile phase A) and $0.1 \%$ formic acid in methanol (mobile phase B). A gradient elution at a flow of $200 \mu \mathrm{L} / \mathrm{min}$ was performed according to the following: 0.5 $\min -5 \%$ B, $2.5 \mathrm{~min}-35 \% \mathrm{~B}, 3.5 \mathrm{~min}-90 \% \mathrm{~B}, 4.5 \mathrm{~min}-90 \% \mathrm{~B}, 4.55 \mathrm{~min}-5 \% \mathrm{~B}$. The total run time was $6 \mathrm{~min}$. The column temperature and the autosampler temperature were kept at $45^{\circ} \mathrm{C}$ and $5{ }^{\circ} \mathrm{C}$, respectively.

Mass spectral ionization and acquisition parameters were optimized on the Xevo G2 Q-TOF MS using electrospray ionization (ESI) in the positive ionization mode. The spray voltage, source temperature, and desolvation temperature were set at $0.5 \mathrm{kV}, 120$ ${ }^{\circ} \mathrm{C}$, and $450{ }^{\circ} \mathrm{C}$, respectively. Nitrogen was used as a desolvation and nebulizer gas. The desolvation gas flow was set at $800 \mathrm{~L} / \mathrm{h}$, and the cone gas flow was $70 \mathrm{~L} / \mathrm{h}$. Data were acquired using the Masslynx software (version 4.0, Waters, Milford, MA, USA).

\subsection{Biology}

\subsubsection{Cell Culture}

The cell line, human colon adenocarcinoma SW40 and human breast carcinoma MCF7 obtained from the Leibniz Institute DSMZ-German Collection of Microorganisms and Cell Cultures (DSMZ, Germany), were grown in RPMI 1640 medium and supplemented 
with $10 \%$ fetal bovine serum (FBS), $100 \mathrm{U} / \mathrm{mL}$ penicillin, $100 \mathrm{lg} / \mathrm{mL}$ streptomycin in a humidified incubator with $5 \% \mathrm{CO}_{2}$ at $37^{\circ} \mathrm{C}$. The culture medium was renewed every 2-3 days. Cell culture media, trypsin, FBS, and antibiotics were purchased from Gibco (Thermo Fisher Scientific Inc., Waltham, MA, USA).

\subsubsection{Experiment Conditions and Cell Viability MTT Assay}

Following MTT experiments, control cells were maintained in normoxia $\left(21 \% \mathrm{O}_{2}, 5 \%\right.$ $\mathrm{CO}_{2}$ ) and cultured in a complete medium with glucose. Hypoxic conditions were achieved by incubating cells in $1 \% \mathrm{O}_{2}, 5 \% \mathrm{CO}_{2}$ incubator (New Brunswick Galaxy 48R, Eppendorf, Hamburg, Germany) and cultured in medium without glucose (RPMI 1640, no glucose, cat. no. 11879020).

For experiments with methotrexate and glucose conjugated MTX, cells were seeded in 96-well plates $\left(8 \times 10^{3}\right.$ cells/well). The next day, the cells were treated with culture medium (control) and different doses of the compounds $(5,10,20 \mu \mathrm{M})$ for $48 \mathrm{~h}$.

Following incubation, an MTT assay was performed. Cell viability was determined by the ability of the mitochondrial enzyme succinate dehydrogenase to convert the yellow tetrazolium salt (MTT) into violet formazan crystals in active cells. After $4 \mathrm{~h}$ of incubation, the medium was removed, and the water-insoluble dye was dissolved by dimethyl sulfoxide (Sigma Aldrich, Munich, Germany), generating the color, whose intensity is directly proportional to the number of viable cells. The absorbance was measured at 570 nm using the Bio-TekBioTek ELX800 multi-well reader (BioTek, Winooski, VT, USA). The percentage of viable cells (VC) was calculated as VC $(100 \%)=($ A of experimental group $/ \mathrm{A}$ of the control group) $\times 100 \%$. MTT experiments were repeated three times, and the figures represent the mean. For further experiments, the concentration of $10 \mu \mathrm{M}$ MTX and Glu-MTX was used to evaluate the motility ability and apoptosis by flow cytometry and immunocytochemistry.

\subsubsection{Wound-Healing Assay}

To analyze the migration properties of MCF-7 and SW480 cells, a wound-healing assay was performed. Cells were seeded on 6-well plates in $1 \times 10^{6} /$ well density to form a confluent monolayer. With a $200 \mu \mathrm{L}$ pipette tip, a linear scratch was made in each sample. The first photograph in time point 0 was taken. Then, the cells were incubated with a dose of $10 \mu \mathrm{M}$ MTX and Glu-MTX for $48 \mathrm{~h}$. After incubation, the second photograph was taken when the scratch was closed in the control cell samples without any treatment. The experiment was repeated three times.

\subsubsection{Flow Cytometry-Apoptosis Assay}

To evaluate the apoptosis rate of cells in the tumor microenvironment, SW480 cells were seeded at a density of $3.5 \times 10^{5} /$ well in a 6 -well culture plate. The next day, cells were treated with MTX or Glu-MTX at a dose of $10 \mu \mathrm{M}$ for $48 \mathrm{~h}$. After treatment, cells were washed with PBS solution, detached by using $0.25 \%$ trypsin in EDTA, centrifuged, and prepared according to the manufacturer's instructions from Annexin V-FITC PI Apoptosis Detection Kit (Abcam, Cambridge, UK). First, cells were suspended in $500 \mu \mathrm{L}$ of $1 \times$ Binding Buffer. Afterward, $5 \mu \mathrm{L}$ of Annexin V (Annexin V-FITC) and $1 \mu \mathrm{L}$ of propidium iodide (PI, $50 \mu \mathrm{g} / \mathrm{mL}$ ) were added to each sample. The samples were incubated for $20 \mathrm{~min}$ in darkness at room temperature. For the evaluation of apoptosis, a BD Accuri C6 flow cytometer (Becton Dickinson, Franklin Lakes, NJ, USA) was used. Control cells, MTX, and Glu-MTX-treated samples were measured in triplicate. The obtained results were analyzed using the BD Accuri 6 Plus Software (Becton, Dickinson, NJ, USA).

\subsubsection{ICC Staining for Apoptosis Detection}

For the immunocytochemical analysis, the apoptotic proteins (Caspase-3, Bax, Bcl-2) were evaluated. MCF-7 cells were seeded on 8 Chamber Eppendorf Cell Imaging Slides (Eppendorf, Germany) at a density of $8 \times 10^{4} /$ well. The following day, $10 \mu \mathrm{M}$ Glu-MTX 
and MTX were added to the wells for $48 \mathrm{~h}$ of incubation. Next, the cells were washed twice in PBS and fixed in 4\% formaldehyde (Polysciences, Warrington, PA, USA) for $10 \mathrm{~min}$ at RT. After PBS washing, cells were permeabilized and incubated in a blocking solution containing 5\% Normal Donkey Serum (Abcam, Bristol, UK), 3\% Bovine Serum Albumin (Sigma Aldrich, Germany), 0.05\% Tween 20 (Sigma Aldrich, Germany), 0.2\% Triton X-100 (Sigma Aldrich, Germany), in PBS for $1 \mathrm{~h}$ at $4{ }^{\circ} \mathrm{C}$. Then the primary antibodies: anti-Bax, anti-Bcl-2, and anti-Caspase 3 (Abcam, UK), in dilution 1:100, were applied, and the cells were incubated overnight at $4{ }^{\circ} \mathrm{C}$. The next day, after PBS washing, the cells were incubated with a secondary anti-rabbit antibody (Sigma Aldrich, Germany) at RT for $1 \mathrm{~h}$. After PBS washing, sections were stained with 3,3'-diaminobenzidine in chromogen solution (Dako EnVision+ Dual Link System-HRP, Agilent, USA) and counterstained with Mayer's hematoxylin for nucleus counterstaining.

The control sample was performed following the above instructions but without incubation with the compounds.

The light microscopy fitted with a digital camera (Nikon, Poland) with dry objectives $20 \times$ and $40 \times$ was used to take the photos.

\section{Conclusions}

The exploration of glycoconjugates for GLUT1-targeted cancer therapy began 25 years ago with the discovery of glufosfamide. Since then, numerous preclinical and clinical trials have been conducted on glucose conjugates in the treatment of various malignancies.

To our knowledge, this is the first time that an evaluation of the biological activity of glucose-conjugate in the tumor microenvironment has been performed. As hypoxia and nutrient stress are known to upregulate GLUT expression on the cancer cell surface and given that GLUTs confer the tumor selectivity of Glu-MTX, the results of our study confirm the viability of the strategy to combat tumor microenvironment-induced drug resistance in solid malignancies through linking of anticancer compounds with glucose. It is of paramount importance to validate anticancer agents' activity in models closer to their "native" microenvironment to improve the dismal success rates in transitioning anticancer agents from the laboratory to the clinic [45].

In summary, this work showed that the conjugation of methotrexate to glucose led to an increase in potency against malignant cells under hypoxia and nutrient stress. Although the finding has been confined to in vitro studies, our observations shed light on a potential therapeutic approach to overcome chemoresistance in cancer.

Supplementary Materials: The following are available online at https:/ /www.mdpi.com/1424-824 7/14/1/13/s1: Figure S1: Mass spectrum of MTX. The molecular ion peak at $m / z 455.1807$ (a) and 455.1798 (b) reflects the mass of free MTX in the intracellular compartment of SW480 cells treated with Glu-MTX and MTX, respectively.

Author Contributions: Conceptualization, M.W., and S.A.; methodology, M.W., S.M., J.W., M.K.; validation, G.P.-G.; formal analysis, P.Z., W.S.; writing-original draft preparation, M.W., G.P.G., S.A.; writing-review and editing, G.P.-G., S.M., M.K.; supervision, P.Z., W.S; project administration, S.A.; funding acquisition, S.A, S.M. All authors have read and agreed to the published version of the manuscript.

Funding: This research was funded by the National Centre for Research and Development, grant number TANGO3/426098/NCBR/2019, and by Wroclaw Medical University, grant number STM.A01 0.20.137.

Data Availability Statement: The data presented in this study are available in this article or asscioiated supplementary material.

Conflicts of Interest: The authors are inventors on submitted patent applications (serial number P.426731). 


\section{References}

1. Roma-Rodrigues, C.; Mendes, R.; Baptista, P.; Fernandes, A. Targeting tumor microenvironment for cancer therapy. Int. J. Mol. Sci. 2019, 20, 840. [CrossRef] [PubMed]

2. Trédan, O.; Galmarini, C.M.; Patel, K.; Tannock, I.F. Drug resistance and the solid tumor microenvironment. J. Natl. Cancer Inst. 2007, 99, 1441-1454. [CrossRef] [PubMed]

3. Correia, A.L.; Bissell, M.J. The tumor microenvironment is a dominant force in multidrug resistance. Drug Resist. Updat. 2012, 15, 39-49. [CrossRef] [PubMed]

4. Nagao, A.; Kobayashi, M.; Koyasu, S.; Chow, C.C.T.; Harada, H. HIF-1-Dependent reprogramming of glucose metabolic pathway of cancer cells and its therapeutic significance. Int. J. Mol. Sci. 2019, 20, 238. [CrossRef] [PubMed]

5. Woźniak, M.; Makuch, S.; Winograd, K.; Wiśniewski, J.; Ziółkowski, P.; Agrawal, S. 6-Shogaol enhances the anticancer effect of 5-fluorouracil, oxaliplatin, and irinotecan via increase of apoptosis and autophagy in colon cancer cells in hypoxic/aglycemic conditions. BMC Complement. Med. Ther. 2020, 20, 141. [CrossRef] [PubMed]

6. Kato, Y.; Maeda, T.; Suzuki, A.; Baba, Y. Cancer metabolism: New insights into classic characteristics. Jpn. Dent. Sci. Rev. 2018, 54, 8-21. [CrossRef]

7. Gocheva, G.; Ivanova, A. A look at receptor ligand pairs for active-targeting drug delivery from crystallographic and molecular dynamics perspectives. Mol. Pharm. 2019, 16, 3293-3321. [CrossRef]

8. Zhu, Y.; Feijen, J.; Zhong, Z. Dual-targeted nanomedicines for enhanced tumor treatment. Nano Today 2018, 18, 65-85. [CrossRef]

9. Minchinton, A.I.; Tannock, I.F. Drug penetration in solid tumours. Nat. Rev. Cancer 2006, 6, 583-592. [CrossRef]

10. Srinivasarao, M.; Low, P.S. LiganD-targeted drug delivery. Chem. Rev. 2017, 117, 12133-12164. [CrossRef]

11. Cantor, J.R.; Sabatini, D.M. Cancer cell metabolism: One hallmark, many faces. Cancer Discov. 2012, 2, 881-898. [CrossRef] [PubMed]

12. Series, C.; Review, L. F-18 FDG PET/CT for detection of malignant involvement of peripheral nerves. Clin. Nucl. Med. 2011, 36, 96-100.

13. Heiden, M.G. Vander targeting cancer metabolism: A therapeutic window opens. Nat. Rev. Drug Discov. 2011, 10, 671-684. [CrossRef] [PubMed]

14. Calvaresi, E.C.; Hergenrother, P.J. Glucose conjugation for the specific targeting and treatment of cancer. Chem. Sci. 2013, 4, 2319. [CrossRef]

15. Srinivasarao, M.; Galliford, C.V.; Low, P.S. Principles in the design of liganD-targeted cancer therapeutics and imaging agents. Nat. Rev. Drug Discov. 2015, 14, 203-219. [CrossRef]

16. Abolmaali, S.S.; Tamaddon, A.M.; Dinarvand, R. A review of therapeutic challenges and achievements of methotrexate delivery systems for treatment of cancer and rheumatoid arthritis. Cancer Chemother. Pharmacol. 2013, 71, 1115-1130. [CrossRef]

17. Kolb, H.C.; Finn, M.G.; Sharpless, K.B. Click chemistry: Diverse chemical function from a few good reactions. Angew. Chem. Int. Ed. 2001, 40, 2004-2021. [CrossRef]

18. Thirumurugan, P.; Matosiuk, D.; Jozwiak, K. Click chemistry for drug development and diverse chemical-biology applications. Chem. Rev. 2013, 113, 4905-4979. [CrossRef]

19. Pohl, J.; Bertram, B.; Hilgard, P.; Nowrousian, M.R.; Stüben, J.; Wießler, M. D-19575-A sugar-linked isophosphoramide mustard derivative exploiting transmembrane glucose transport. Cancer Chemother. Pharmacol. 1995, 35, 364-370. [CrossRef]

20. Granchi, C.; Fortunato, S.; Minutolo, F. Anticancer agents interacting with membrane glucose transporters. Med. Chem. Commun. 2016, 7, 1716-1729. [CrossRef]

21. Barnett, J.E.G.; Holman, G.D.; Munday, K.A. Structural requirements for binding to the sugar-transport system of the human erythrocyte. Biochem. J. 1973, 131, 211-221. [CrossRef] [PubMed]

22. Mueckler, M.; Makepeace, C. Model of the exofacial substrate-binding site and helical folding of the human Glut1 glucose transporter based on scanning mutagenesis. Biochemistry 2009, 48, 5934-5942. [CrossRef] [PubMed]

23. Agarwal, P.; Bertozzi, C.R. Site-specific antibody-drug conjugates: The nexus of bioorthogonal chemistry, protein engineering, and drug development. Bioconjug. Chem. 2015, 26, 176-192. [CrossRef] [PubMed]

24. Tiwari, V.K.; Mishra, B.B.; Mishra, K.B.; Mishra, N.; Singh, A.S.; Chen, X. Cu-catalyzed click reaction in carbohydrate chemistry. Chem. Rev. 2016, 116, 3086-3240. [CrossRef]

25. Krawczyk, M.; Pastuch-Gawołek, G.; Pluta, A.; Erfurt, K.; Domiński, A.; Kurcok, P. 8-Hydroxyquinoline glycoconjugates: Modifications in the linker structure and their effect on the cytotoxicity of the obtained compounds. Molecules 2019, $24,4181$. [CrossRef]

26. Le Roux, A.; Meunier, S.; Le Gall, T.; Denis, J.M.; Bischoff, P.; Wagner, A. Synthesis and radioprotective properties of pulvinic acid derivatives. Chem. Med. Chem. 2011, 6, 561-569. [CrossRef]

27. Zemplén, G.; Pacsu, E. Über die Verseifung acetylierter Zucker und verwandter Substanzen. Ber. Dtsch. Chem. Ges. 1929, 62, 1613-1614. [CrossRef]

28. De Figueiredo, R.M.; Suppo, J.S.; Campagne, J.M. Nonclassical routes for amide bond formation. Chem. Rev. 2016, 116, 12029-12122. [CrossRef]

29. Kim, S.; Lee, J.I.; Kim, Y.C. A simple and mild esterification method for carboxylic acids using mixed carboxylic-carbonic anhydrides. J. Org. Chem. 1985, 50, 561-565. [CrossRef] 
30. Watkins, B.E.; Kiely, J.S.; Rapoport, H. Synthesis of oligodeoxyribonucleotides using N-benzyloxycarbonyl-blocked nucleosides. J. Am. Chem. Soc. 1982, 104, 5702-5708. [CrossRef]

31. Pandey, M.; Prasad, S.; Tyagi, A.; Deb, L.; Huang, J.; Karelia, D.; Amin, S.; Aggarwal, B. Targeting cell survival proteins for cancer cell death. Pharmaceuticals 2016, 9, 11. [CrossRef] [PubMed]

32. Wang, M.; Zhao, J.; Zhang, L.; Wei, F.; Lian, Y.; Wu, Y.; Gong, Z.; Zhang, S.; Zhou, J.; Cao, K.; et al. Role of tumor microenvironment in tumorigenesis. J. Cancer 2017, 8, 761-773. [CrossRef] [PubMed]

33. Doktorova, H.; Hrabeta, J.; Khalil, M.A.; Eckschlager, T. Hypoxia-induced chemoresistance in cancer cells: The role of not only HIF-1. Biomed. Pap. 2015, 159, 166-177. [CrossRef] [PubMed]

34. Li, J.; Shi, M.; Cao, Y.; Yuan, W.; Pang, T.; Li, B.; Sun, Z.; Chen, L.; Zhao, R.C. Knockdown of hypoxia-inducible factor-1 $\alpha$ in breast carcinoma MCF-7 cells results in reduced tumor growth and increased sensitivity to methotrexate. Biochem. Biophys. Res. Commun. 2006, 342, 1341-1351. [CrossRef] [PubMed]

35. Sanna, K.; Rofstad, E.K. Hypoxia-induced resistance to doxorubicin and methotrexate in human melanoma cell lines in vitro. Int. J. Cancer 1994, 58, 258-262. [CrossRef] [PubMed]

36. Petit, C.; Gouel, F.; Dubus, I.; Heuclin, C.; Roget, K.; Vannier, J.P. Hypoxia promotes chemoresistance in acute lymphoblastic leukemia cell lines by modulating death signaling pathways. BMC Cancer 2016, 16, 746. [CrossRef]

37. Nishimoto, A.; Kugimiya, N.; Hosoyama, T.; Enoki, T.; Li, T.-S.; Hamano, K. HIF-1 activation under glucose deprivation plays a central role in the acquisition of anti-apoptosis in human colon cancer cells. Int. J. Oncol. 2014, 44, 2077-2084. [CrossRef]

38. Mathews, E.H.; Stander, B.A.; Joubert, A.M.; Liebenberg, L. Tumor cell culture survival following glucose and glutamine deprivation at typical physiological concentrations. Nutrition 2014, 30, 218-227. [CrossRef]

39. Hu, Y.L.; Yin, Y.; Liu, H.Y.; Feng, Y.Y.; Bian, Z.H.; Zhou, L.Y.; Zhang, J.W.; Fei, B.J.; Wang, Y.G.; Huang, Z.H. Glucose deprivation induces chemoresistance in colorectal cancer cells by increasing ATF4 expression. World J. Gastroenterol. 2016, 22, 6235-6245. [CrossRef]

40. Fu, J.; Yang, J.; Seeberger, P.H.; Yin, J. Glycoconjugates for glucose transporter-mediated cancer-specific targeting and treatment. Carbohydr. Res. 2020, 498, 108195. [CrossRef]

41. Deng, D.; Yan, N. GLUT, SGLT, and SWEET: Structural and mechanistic investigations of the glucose transporters. Protein Sci. 2016, 25, 546-558. [CrossRef] [PubMed]

42. Barron, C.C.; Bilan, P.J.; Tsakiridis, T.; Tsiani, E. Facilitative glucose transporters: Implications for cancer detection, prognosis and treatment. Metabolism 2016, 65, 124-139. [CrossRef]

43. Parks, S.K.; Cormerais, Y.; Marchiq, I.; Pouyssegur, J. Hypoxia optimises tumour growth by controlling nutrient import and acidic metabolite export. Mol. Aspects Med. 2016, 47, 3-14. [CrossRef]

44. Yang, Q.R.; Qiao, W.H.; Zhang, S.M.; Qu, J.P.; Liu, D.L. Synthesis and characterization of a new cationic galactolipid with carbamate for gene delivery. Tenside Surf. Det. 2010, 5, 294-299. [CrossRef]

45. Bhattacharya, B.; Omar, M.F.M.; Soong, R. The Warburg effect and drug resistance. Br. J. Pharmacol. 2016, 173, 970-979. [CrossRef] [PubMed] 